\title{
Autoimmune Myocarditis Induced in Mice by Cardiac C-Protein Cloning of Complementary DNA Encoding Murine Cardiac C-Protein and Partial Characterization of the Antigenic Peptides
}

\author{
Hideko Kasahara, ${ }^{\star \ddagger}$ Masahiko Itoh, ${ }^{\ddagger}$ Tsuyoshi Sugiyama, ${ }^{\S}$ Nobuo Kido, ${ }^{\S}$ Hiroshi Hayashi, * Hidehiko Saito, * \\ Shoichiro Tsukita, ${ }^{\star}$ and Nobuo Kato ${ }^{\$}$ \\ * First Department of Internal Medicine, Nagoya University School of Medicine, Nagoya 466, Japan; ${ }^{\ddagger}$ Department of Information \\ Physiology, National Institute for Physiological Sciences, Okazaki 444, Japan; and ${ }^{\S}$ Department of Bacteriology, Nagoya University \\ School of Medicine, Nagoya 466, Japan
}

\begin{abstract}
Autoimmune myocarditis is considered to play a major role in the pathogenesis of dilated cardiomyopathy. A new autoimmune myocarditis model was attained by repeated immunization using murine cardiac $C$-protein with the immunological adjuvant, Klebsiella pneumoniae $\mathrm{O3}$ lipopolysaccharide. For further analysis of a pathological epitope, the cDNA encoding C-protein was isolated; a fusion protein encoded by part of this cDNA induced myocarditis in SMA mice as well as in three other strains: DBA/1J $\left({\mathrm{H}-2^{\mathrm{q}}}^{\mathrm{a}}\right), \mathrm{O20} /$ A $\left(\mathrm{H}-2^{\mathrm{pz} 1}\right)$, and SJL $\left(\mathrm{H}-2^{\mathrm{s}}\right)$. The nucleotide sequence and its deduced amino acid analysis revealed that this protein had immunoglobulin-like and fibronectin-like repeats. This study provides a new animal model of autoimmune myocarditis which may shed light on the pathogenesis of dilated cardiomyopathy. (J. Clin. Invest. 1994. 94:1026-1036.) Key words: autoimmune myocarditis • immunoglobulin superfamily $\bullet$ C-protein $\cdot$ dilated cardiomyopathy $\bullet$ lipopolysaccharide
\end{abstract}

\section{Introduction}

Dilated cardiomyopathy (DCM $)^{1}$ is a progressive disease characterized by a dilated heart with impaired systolic function. Since the pathogenesis remains obscure, it is usually diagnosed by ruling out valvular or coronary heart disease, excessive alcohol intake, high blood pressure, and systemic disorders that exhibit accompanying heart impairment, such as diabetes $(1-3)$.

Infective myocarditis, in particular myocarditis associated with Coxsackie virus B3 (CB3), metabolic disease, or micro-

Address correspondence to Nobuo Kato, M.D., Department of Bacteriology, Nagoya University School of Medicine, 65 Tsurumai-cho, Showaku, Nagoya 466, Japan.

Received for publication 14 January 1994 and in revised form 14 April 1994

1. Abbreviations used in this paper: $\mathrm{CB} 3$, Coxsackie virus $\mathrm{B} 3$; DCM, dilated cardiomyopathy; Fn, fibronectin; KO3 LPS, Klebsiella pneumoniae $\mathrm{O} 3$ lipopolysaccharide; MBP, maltose binding protein; TCR, T cell receptor.

J. Clin. Invest.

(C) The American Society for Clinical Investigation, Inc. 0021-9738/94/09/1026/11 \$2.00

Volume 94, September 1994, 1026-1036 vascular spasm is implicated in the pathogenesis of DCM (3, 4 ). However, several lines of evidence suggest that DCM is preceded by autoimmune myocarditis; autoantibodies against various cardiac proteins (5-8), abnormal expression of class II HLA-DR antigens on the myocardium, and a familial background support this notion (9-11). Although there is clear evidence that the autoantibodies of DCM patients react to several different proteins, the epitopes for experimental autoimmune myocarditis models and DCM still remain limited. Therefore, the cardiac muscle protein responsible for autoimmune myocarditis causing DCM must be identified.

Autoimmune myocarditis has been experimentally induced by cardiac myosin (12), a mixture of membranous proteins (13), and crude heart extract $(14,15)$. As a tissue-specific experimental autoimmune model (16-23), we reported myocarditis induced by syngeneic heart extract together with Klebsiella pneumoniae $\mathrm{O} 3$ lipopolysaccharide (KO3 LPS), an immunological adjuvant, in SMA mice (24). Here, we demonstrated that $\mathrm{C}$-protein is the primary antigen which induces myocarditis. In addition, we cloned the cDNA encoding Cprotein and identified part of the location of the antigenic epitope in various mice strains including SMA, DBA/1J, SJL, and O20/A.

\section{Methods}

Mice

SMA mice $\left(\mathrm{H}-2 \mathrm{~K}^{\mathrm{s}}, \mathrm{D}^{\text {nondefined }}\right)$ were maintained at the Institute for Laboratory Animal Research, Nagoya University School of Medicine. The H-2D haplotype has not yet been confirmed; it does not react to

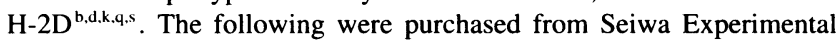
Animals, Ltd. (Fukuoka, Japan) or bred in our Institute for Laboratory Animal Research: DBA/1J $\left(\mathrm{H}-2^{\mathrm{q}}\right), \mathrm{DBA} / 2 \mathrm{~J}\left(\mathrm{H}-2^{\mathrm{d}}\right), \mathrm{BALB} / \mathrm{c}\left(\mathrm{H}-2^{\mathrm{d}}\right)$, C57BL/6 (H-2 $\left.{ }^{\mathrm{b}}\right), \mathrm{O} 20 / \mathrm{A}\left(\mathrm{H}-2^{\mathrm{p} 21}\right), \mathrm{SJL}\left(\mathrm{H}-2^{\mathrm{s}}\right), \mathrm{A} / \mathrm{J}\left(\mathrm{H}-2^{\mathrm{a}}\right), \mathrm{AKR} / \mathrm{J}$ $\left(\mathrm{H}-2^{k}\right)$, and $\mathrm{C} 3 \mathrm{H} / \mathrm{He}\left(\mathrm{H}-2^{\mathrm{k}}\right)$.

\section{Antigen preparation}

Heart extract. The mouse heart was resected under deep anesthesia, frozen, and kept at $-80^{\circ} \mathrm{C}$ until antigen preparation. All subsequent procedures were carried out at $4^{\circ} \mathrm{C}$. The heart was rinsed and soaked in $0.01 \mathrm{M}$ PBS, at pH 7.2, homogenized in $10 \mathrm{vol}$ of PBS, and centrifuged at $700 \mathrm{~g}$ for $5 \mathrm{~min}$. The supernatant was kept at $-80^{\circ} \mathrm{C}$ until injection.

$150-k D-$ rich fraction and $150-k D$ protein. High-salt extract of mouse heart was prepared according to the method of Neu et al. (25) with some modifications. The extract was passed through a Sepharose 4B gel filtration column (Pharmacia AB, Uppsala, Sweden) rather than Biogel A-15 m resin (Bio-Rad Laboratories, Richmond, CA). The fractions containing the $150-\mathrm{kD}$ protein were collected, dialyzed against $1 / 10$ PBS, and then freeze-dried and resuspended in water. To purify the 
Table I. Induction of Murine Autoimmune Myocarditis in SMA Mice Using Different Antigens*

\begin{tabular}{|c|c|c|c|}
\hline Experiment & Immunogen & $\begin{array}{c}\text { Antigen } \\
\text { dose } \times \\
\text { times }\end{array}$ & $\begin{array}{l}\text { Induction of } \\
\text { myocarditis }\end{array}$ \\
\hline 1 & $\begin{array}{l}\text { Heart extract }(10 \%) \\
+ \text { KO3 LPS }\end{array}$ & $100 \mu \mathrm{l} \times 5$ & $53 \%(10 / 19)$ \\
\hline 2 & $\begin{array}{l}\text { 150-kD-rich fraction } \\
+ \text { KO3 LPS }\end{array}$ & $100 \mu \mathrm{g} \times 3$ & $88 \%(7 / 8)$ \\
\hline \multirow[t]{4}{*}{3} & $\begin{array}{l}\text { Electroeluted } 150-\mathrm{kD} \text { protein } \\
+ \text { KO3 LPS }\end{array}$ & $50 \mu \mathrm{g} \times 3$ & $100 \%(7 / 7)$ \\
\hline & & $10 \mu \mathrm{g} \times 3$ & $0 \%(0 / 3)$ \\
\hline & & $2 \mu \mathrm{g} \times 3$ & $0 \%(0 / 2)$ \\
\hline & Electroeluted $150-\mathrm{kD}$ protein & $50 \mu \mathrm{g} \times 3$ & $0 \%(0 / 2)$ \\
\hline 4 & $\begin{array}{l}\text { Electroeluted skeletal C-protein } \\
+ \text { KO3 LPS }\end{array}$ & $50 \mu \mathrm{g} \times 6$ & $0 \%(0 / 3)$ \\
\hline 5 & Native C-protein + KO3 LPS & $100 \mu \mathrm{g} \times 3$ & $83 \%(5 / 6)$ \\
\hline 6 & PBS + KO3 LPS & $100 \mu \mathrm{l} \times 8$ & $0 \%(0 / 20)$ \\
\hline
\end{tabular}

* Antigens mixed with $100 \mu \mathrm{g} \mathrm{KO3} \mathrm{LPS} \mathrm{or} \mathrm{without} \mathrm{LPS} \mathrm{were} \mathrm{injected} \mathrm{at} \mathrm{4-wk}$ intervals.

$150-\mathrm{kD}$ protein, this fraction was separated with $7.5 \%$ SDS-polyacrylamide gel ( $5 \mathrm{~mm}$ thick, $13 \mathrm{~cm}$ wide, and $9 \mathrm{~cm}$ high). After staining with Coomassie blue, the $150-\mathrm{kD}$ bands were cut from the gel and eluted electrophoretically (model 422 electroeluter; Bio-Rad Laboratories). The eluted protein, precipitated by the addition of $10 \mathrm{vol}$ of acetone, was then resuspended in water.

Native C-protein. C-protein was purified by the method of Hartzell and Glass (26) with some modifications. In place of a $2.5 \times 35-\mathrm{cm}$ hydroxyapatite column (high-resolution powder; Calbiochem-Novabiochem Corp., San Diego, CA) and a $1.6 \times 35$-cm DEAE-Sephacel column (Pharmacia AB), we used $1.5 \times 3.8$-cm HA-ultrogel (Sepracor S.A., Villeneuve la Garenne, France) and $1.5 \times 3.8-\mathrm{cm} Q$ Sepharose Fast Flow (Pharmacia AB). Skeletal muscle C-protein was prepared from murine sacral muscles by the same method and further purified electrophoretically.

Human cardiac $C$-protein. A human left ventricle was obtained at the Nagoya University Hospital from a 70-yr-old female who died of pancreatic cancer. The heart, which was resected at autopsy about $1 \mathrm{~h}$ after death, was histologically normal. The heart tissue was rinsed in PBS and kept at $-80^{\circ} \mathrm{C}$ until sample preparation. C-protein was purified by the method described above.

\section{KO3 LPS preparation}

KO3 LPS as an adjuvant was prepared as described previously $(27,28)$ from the culture supernatant of a decapsulated mutant strain LEN-1 (03: $\left.\mathrm{K}^{-}\right)$derived from the $K$. pneumoniae Kasuya strain. In brief, the microorganisms were cultured in a synthetic medium at $37^{\circ} \mathrm{C}$ for $2 \mathrm{~d}$. The organisms were killed by the addition of formalin and then concentrated 10-fold. After removal of bacterial cells by centrifugation, LPS in the supernatant was precipitated by adding ethanol and then treated three times with a chloroform/butanol mixture (1:5) for deproteinization.

\section{Induction and assessment of myocarditis}

6-8-wk-old mice were injected subcutaneously in the inguinal region with either $100 \mu$ l of the heart extract or PBS, 150-kD-rich fraction ( 100 $\mu \mathrm{g})$, native C-protein ( $100 \mu \mathrm{g}), 50 \mu \mathrm{g}$ of electrophoretically purified Cprotein, and fusion proteins (100 and $50 \mu \mathrm{g}$ ) together with KO3 LPS at 4-wk intervals. When mice developed clinical symptoms such as cyanosis and dyspnea, they were bled from the subaxillary artery under ether anesthesia and then killed by an overdose of anesthetic. All other mice were followed for $4 \mathrm{wk}$ after the last immunization. For the diagnostic evaluation by the cardiac histology, all hearts were resected, fixed in $20 \%$ formalin/PBS, and stained by hematoxylin and eosin. Mice were considered negative for myocarditis when they had not developed myocarditis even after three repeated immunizations with the purified cardiac C-protein, or five times with the heart extract and fusion proteins, or six times with skeletal C-protein and PBS. Fusion protein P16-4 at $100 \mu \mathrm{g}$ induced myocarditis in all SMA mice before the last immunization.
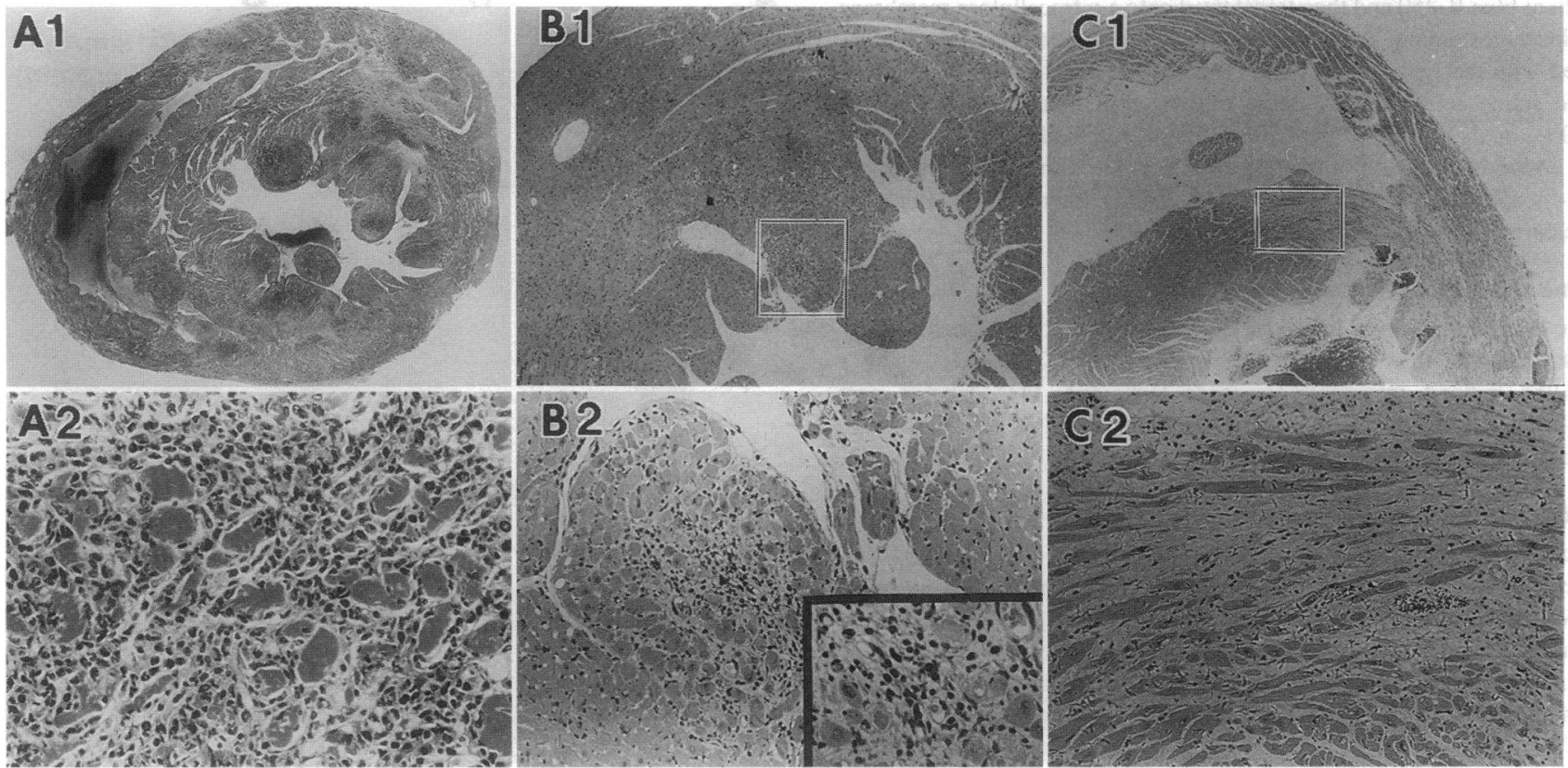

Figure 1. Autoimmune myocarditis induced by repeated injections of syngeneic heart extract mixed with KO3 LPS. Inflammatory responses were varied in individual mice from severe changes $(A 1$ and $A 2)$ to minimum changes $(B 1$ and $B 2)$ and chronic changes $(C 1$ and $C 2)$. Note the diffuse myocyte necrosis and inflammatory infiltrates (hematoxylin and eosin staining). 

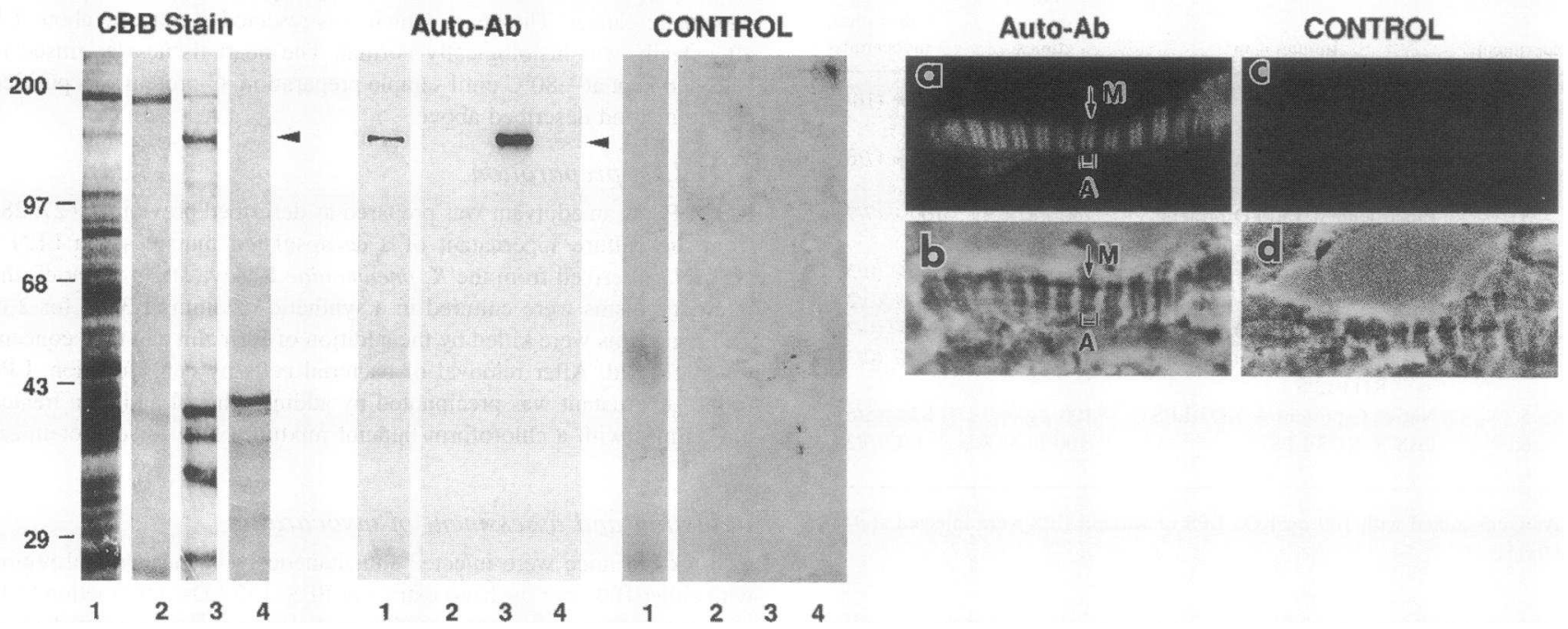

Figure 2. $150-\mathrm{kD}$ protein is the dominant antigen recognized by the autoantibody from heart homogenate immunized mice. $(A)$ SDS-polyacrylamide gel electrophoretic banding pattern of the heart extract and fractionation of high-salt extract of murine heart: lane 1 , heart extract; lane 2, myosin $(200 \mathrm{kD})$; lane 3, 150-kD protein; and lane 4, actin $(43 \mathrm{kD})$. (B) Accompanying immunoblot with sera (Ab 1) obtained from immunized mice and preimmunization mice. The band at $\sim 150 \mathrm{kD}$ was detected preferentially by the autoantibody but not by the preimmunization sera (CONTROL). Note that preimmunization sera was diluted at 1:100, and autoantibody was diluted at 1:500. In addition, the nitrocellulose transfer was developed longer than that of autoantibody. $(C)$ Immunofluorescent microscopic localization of the 150-kD protein in frozen sections of mouse heart ( $a$ and $c$ ) and phase-contrast image ( $b$ and $d$ ). The $150-\mathrm{kD}$ protein was concentrated at the level of the $\mathrm{A}$ band with an unstained region in the center of each band $(a)$. Preimmunization sera did not stain the cardiac cell $(c)$.

\section{Gel electrophoresis and immunoblotting}

SDS-PAGE was performed according to the discontinuous Tris-glycine system of Laemmli (29). The slab gels were stained with Coomassie brilliant blue R-250 and then transferred onto a nitrocellulose membrane for immunostaining. Strips of the nitrocellulose membranes were incubated with test sera from immunized mice (diluted 1:500 in Tris-buffered saline containing 5\% skim milk), preimmunized mice (diluted 1:100), mAb, and DCM patients or control sera (diluted 1:40) for $1 \mathrm{~h}$. For antibody detection, a blotting detection kit with alkaline phosphatase-conjugated immunoglobulin (Amersham International, Buckinghamshire, UK) was used.

\section{Immunohistochemistry}

Sera, diluted 1:50, were tested on cryostat sections of the hearts (2- $\mu \mathrm{m}$ thick, $1 \%$ formaldehyde fixed, $0.2 \%$ Triton $X-100$ treated), using a standard indirect immunofluorescence technique. FITC-labeled goat anti-mouse Ig (Amersham International) was used at a 1:50 dilution. Sections were viewed on an ultraviolet microscope.

\section{Isolation and sequencing of cDNAs}

Mouse heart $\lambda g t 11$, oligo(dT)-primed expression cDNA library was purchased from Clontech Laboratories, Inc. (Palo Alto, CA). The initial cDNA clone, C26, was isolated using autoantibody of a myocarditis mouse according to the method described by Huynh et al. (30). The C26 fragment was then labeled by means of the DIG labeling kit (Boehringer Mannheim Corp., Indianapolis, IN) and used to screen the library according to the procedure developed by the manufacturer. Three clones, $\mathrm{C} 16, \mathrm{C} 31$, and $\mathrm{C} 35$, were isolated.

All clones were subcloned into pBluescript SK(-) and sequenced with 7-deaza Sequenase Version 2.0 kit (United States Biochemical Corp., Cleveland, $\mathrm{OH}$ ). To determine the sequence of long inserts, the

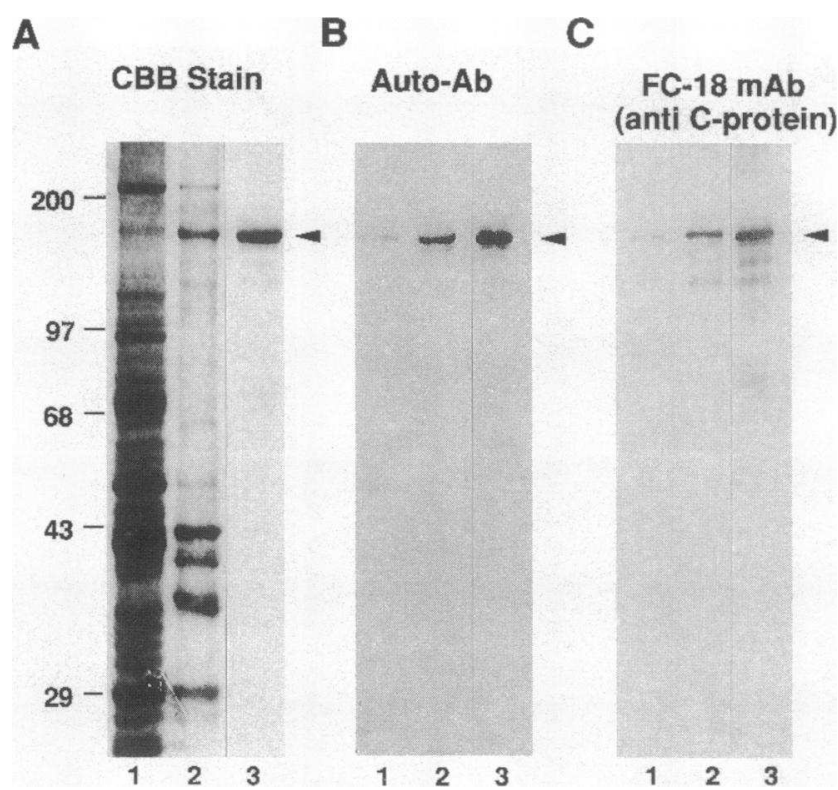

Figure 3. Identification of the $150-\mathrm{kD}$ protein and C-protein. $(A)$ Coomassie blue-stained gel of heart extract (lane 1), 150-kD-rich (lane 2 ), and purified C-protein (lane 3). Accompanying immunoblots with the autoantibody $(\mathrm{Ab} 1)(B)$ and with anti-C-protein mAb FC-18 (35) $(C)$, which was donated by T. Obinata (Chiba University, Japan). 
A

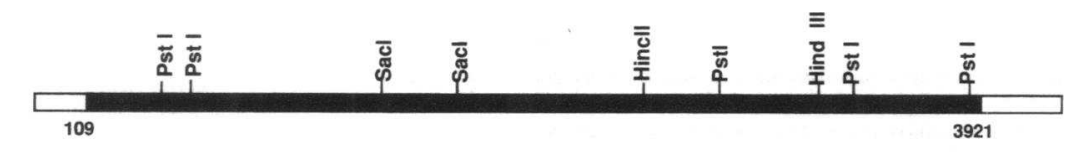

B

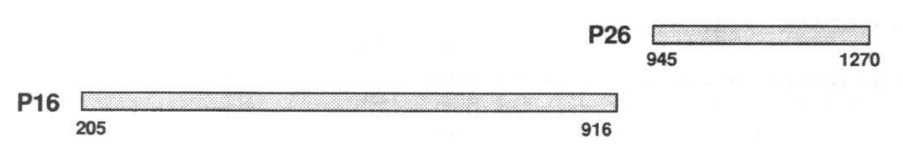

Figure 4. Mouse cardiac C-protein cDNAs and fusion protein fragments. $(A)$ Restriction map and cDNA fragments. Closed box, the coding region; open box, the untranslated region. $(B)$ Two fusion proteins (P16-4 and P26) are expressed in E. coli from Pst1 fragment of C16 (residue 205-916) and C26 (residue 945-1270). plasmids were linearized and unidirectionally deleted using the Deletion Kit for Kilo-Sequence (Takara Shuzo Co., Ltd., Kyoto, Japan). The deletion mutants were also sequenced, as described above.

\section{Production of fusion proteins in Escherichia coli}

C26 and the PstI-PstI fragment of clone C16 were inserted in frame into the pMAL-CRI (New England Biolabs Inc., Beverly, MA). Fusion proteins and maltose binding protein (MBP) were expressed in XL1/ Blue (RIKEN DNA Bank, Tsukuba, Japan) which was synthesized according to the procedure described by the manufacturer, and $E$. coli lysate was separated by SDS-PAGE and purified electrophoretically as mentioned above.

\section{DCM patients}

The DCM patients were 10 men and 6 women, aged 37-67 yr (mean \pm SD; $53.9 \pm 9.4 \mathrm{yr}$ ). They were diagnosed with DCM in accordance with the criteria described by Caforio et al. (8). Echocardiographic assessments showed that left ventricular end-diastolic and endsystolic echocardiographic dimensions were $54-74 \mathrm{~mm}(63.1 \pm 6.2)$ and $42-68 \mathrm{~mm}(54.0 \pm 8.4)$, respectively, and the ejection fraction was $15-$ $54 \%$ (34.9 \pm 12.3$)$. For controls, we examined 83 healthy volunteers, aged 20-54 yr (mean $41.0 \mathrm{yr}$ ).

\section{Results}

Autoantibody recognizes a $150-k D$ protein. Myocarditis was induced by the immunization of the combination of heart extract and KO3 LPS in 10 of 19 mice (Table I). This myocarditis was histologically characterized by inflammatory responses such as myocyte necrosis and lymphocyte infiltrates, from minimum (Fig. $1 B$ ) to severe changes (Fig. $1 A$ ) and chronic changes (Fig. $1 C$ ). Sera (Ab 1), obtained from the myocarditis mice, showed a protein with a molecular mass of $150 \mathrm{kD}$ on immunoblotting (Fig. $2 \mathrm{~B}$, lane 1 ). Based on the Coomassie stain of heart homogenate (Fig. $2 A$, lane 1 ), it was suspected that the $150-\mathrm{kD}$ protein is one of the major constituent proteins in the cardiac cell. First, we passed the crude high-salt extract from the mouse heart through a gel filtration column and analyzed each fraction by immunoblotting with Ab 1 . As Fig. 2 A shows, the $150-\mathrm{kD}$ protein was concentrated in the fractions eluted after myosin (Fig. $2 \mathrm{~A}$, lane 3 ).

The fractions containing the $150-\mathrm{kD}$ protein $(100 \mu \mathrm{g})$ and the electrophoretically purified $150-\mathrm{kD}$ protein $(50 \mu \mathrm{g})$ induced myocarditis in almost all immunized mice (87.5 and 100\%)
(Table I). The incidence of myocarditis was dose dependent. When 10 and $2 \mu \mathrm{g}$ of electroeluted $150-\mathrm{kD}$ protein were used, no myocarditis was induced (Table I). Thus we suspect that at least $50 \mu \mathrm{g}$ of C-protein is necessary for the induction of myocarditis. In control experiments, electrophoretically purified skeletal-type C-protein ( $50 \mu \mathrm{g}$ ) from murine sacralis muscle failed to induce either myocarditis or myositis (back and leg muscles were examined). PBS (100 $\mu 1)$ mixed with KO3-LPS did not induce myocarditis in SMA mice under the same experimental conditions (Table I).

Autoantibodies from the $150-\mathrm{kD}$ protein-induced myocarditis mice showed immunofluorescent stained $A$ bands with unstained region in the center of each band (Fig. $2 C$ ).

The 150-kD protein is C-protein, and purified C-protein induces myocarditis. Due to the molecular mass $(150 \mathrm{kD})$, the localization at the A bands, and the abundance in the heart, we were encouraged to examine whether the $150-\mathrm{kD}$ protein and C-protein were identical. C-protein has been identified as one of the major constituents of thick filaments from skeletal muscle and shows a molecular mass of $\sim 150 \mathrm{kD}$ (31). The existence of cardiac-type C-protein has also been reported (32-34). Therefore, we performed immunoblotting analysis of the heart homogenate (Fig. $3 A$, lane 1 ) and the $150-\mathrm{kD}-$ rich fractions (Fig. $3 A$, lane 2) with anti-C-protein mAb, FC-18 (35). This $\mathrm{mAb}$ clearly recognized the $150-\mathrm{kD}$ protein as well as $\mathrm{Ab} 1$ (Fig. 3, $B$ and $C$ ).

Then we purified $C$-protein from the murine heart in a native form (26), using the conventional column chromatography (Fig. $3 A$, lane 3$)$. The purified native C-protein $(100 \mu \mathrm{g})$ effectively induced myocarditis in SMA mice $(83 \%, n=6)$ when immunized together with KO3 LPS (Table I).

Isolation of $c D N A$ encoding the cardiac $C$-protein. Using the autoantibody (Ab 1), we screened mouse heart $\lambda \mathrm{gt} 11$ expression libraries to isolate cDNA fragments encoding the 150$\mathrm{kD}$ protein (C-protein) and cloned one positive phage recombinant, C26 (Fig. 4). To obtain the full length of this protein, we then screened the same libraries with a probe from the $5^{\prime}$ end of C26. Through a series of rescreening experiments, four overlapping clones including $\mathrm{C} 26$ were isolated, and their restriction maps showed that they overlap with each other and constitute a single type of cDNA.

Fig. 5 shows the complete nucleotide and deduced amino 


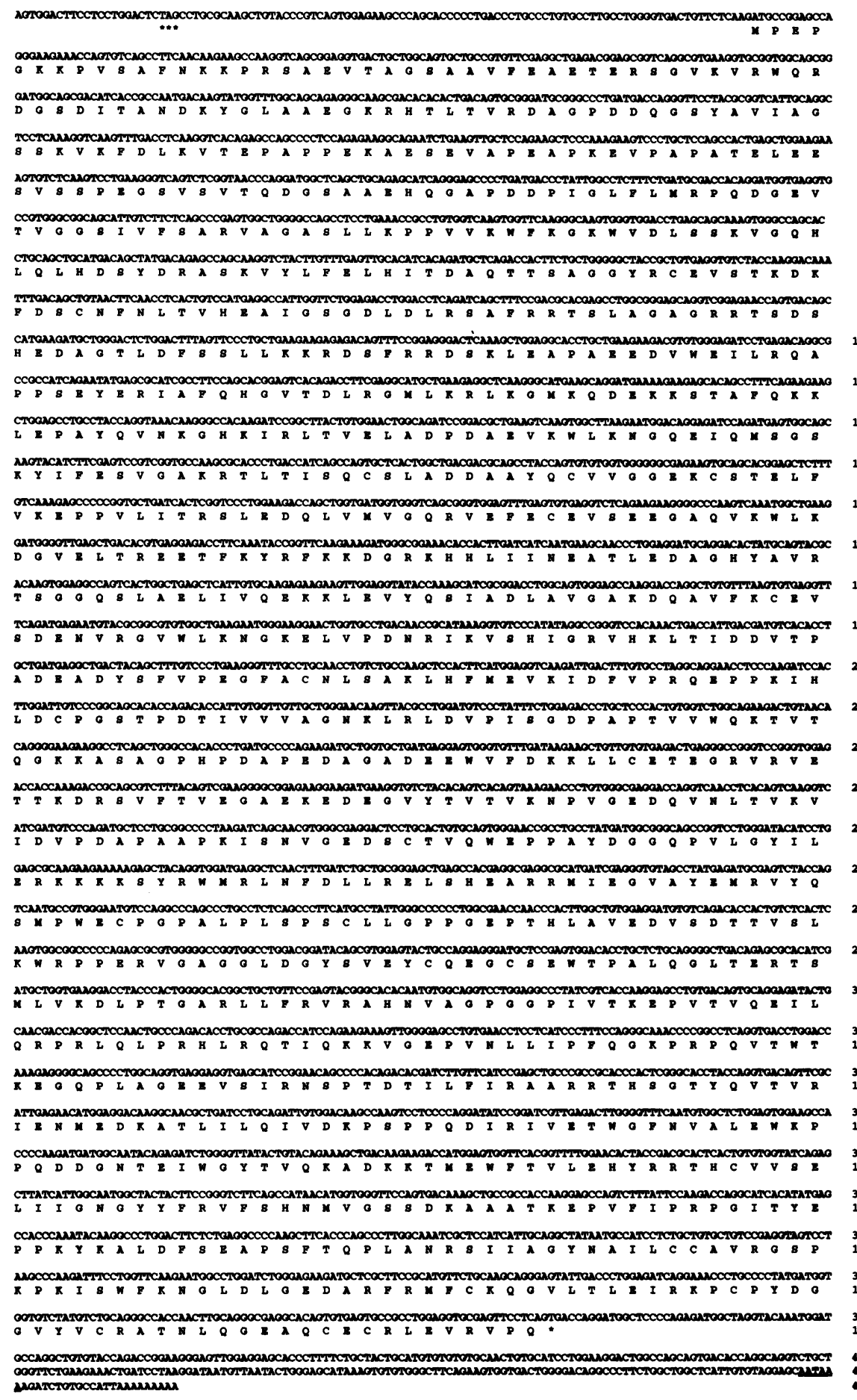

120 240 124 600 720
204 240 1080
326 364 1320 44 1560 1580 604 641 2160
684 2280
724 2400 2520
804 2640
844 2760
884 2880
924 3000 964 3120
1004 3240 3260 1124 3600
1164 3720 204 3840 1244 3960
1270 1270
4080
4200
4224
Figure 5. Nucleotide and deduced amino acid sequence of mouse heart $C$-protein. The stop codon TGA (residues 3919-3921) and the stop codon preceding the open reading frame (residues 22-24) are marked with asterisks. The polyadenylation consensus sequences found in the $3^{\prime}$ untranslated sequences are underlined. acid sequences of the cloned molecule. In the 4224-nucleotide sequence, the longest open reading frame, with 3810 nucleotides, begins from the ATG codon at nucleotide 109 and ends with the TGA signal for termination at nucleotide 3919 , thereby coding for a protein of 1,270 amino acids with the predicted mass of 140,621 daltons. The molecular mass of this protein on SDS-PAGE $(150 \mathrm{kD})$, the high $\mathrm{G}+\mathrm{C}$ content at positions 25-108 (64\%), and one in-frame TAG stop codon (residue 22-24) precedes the ATG start codon (residue 109-111).
Comparison of the sequence of cardiac and skeletal C-protein. Recently, chicken $(36,37)$ and human skeletal C-protein (38) were cloned. Examination of the amino acid sequence of mouse cardiac C-protein revealed that this C-protein has 53\% sequence identity with chicken fast isoform and $45 \%$ with human slow isoform by means of the amino acid homology program (GENETYX Software Development Co., Tokyo, Japan). The cardiac isoform (1,270 amino acids) is $\sim 140$ amino acids longer than two skeletal isoforms $(1,132$ amino acids in chicken 


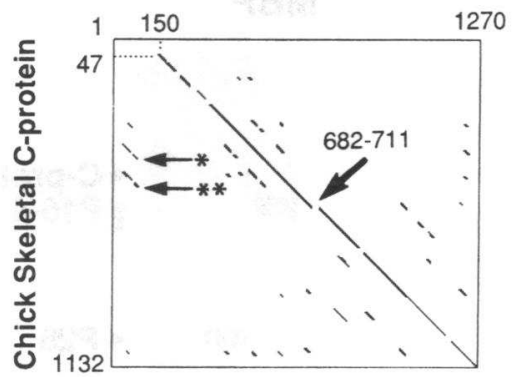

B

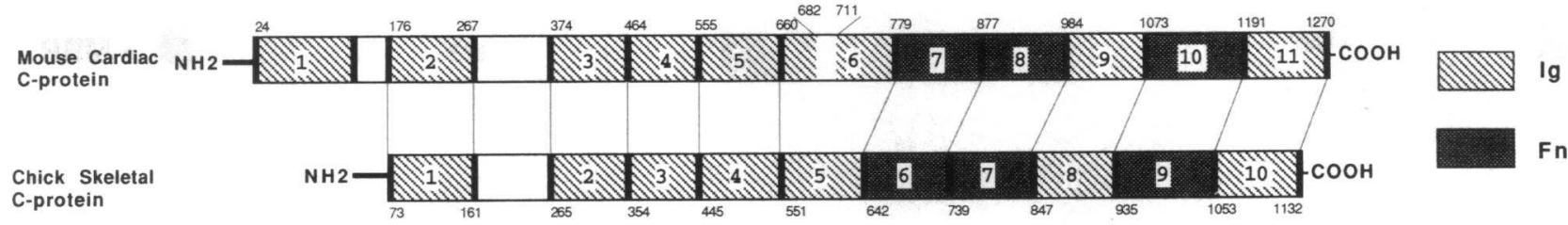

C

IgG-like domains

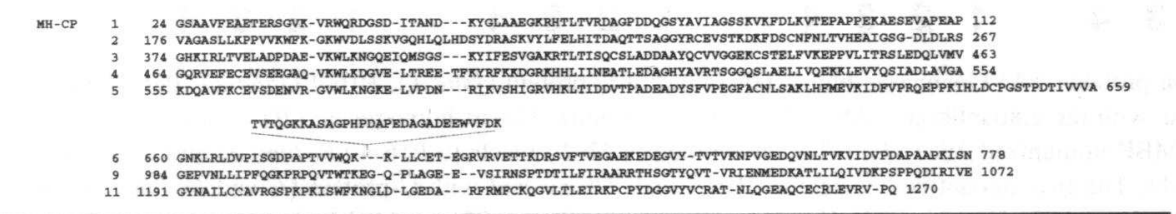

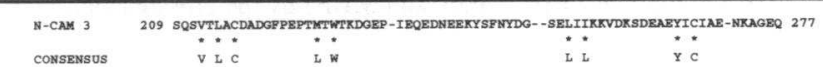

Fibronectin-like domains

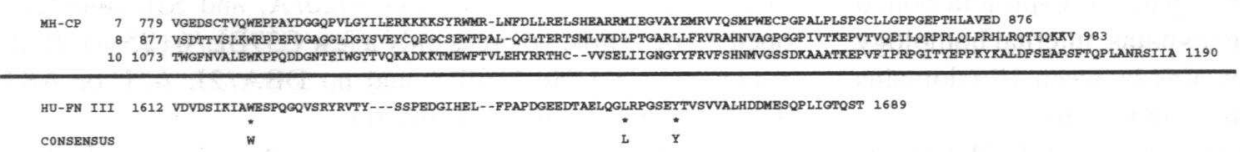

Figure 6. Analysis of the structure of mouse cardiac C-protein. (A) Diagonal dot matrix comparison between chick skeletal fast-isoform C-protein (37) and mouse cardiac C-protein was made using the GENETYX HARRPLOT program (unit size 22, and dot plot score 2.1) (39). Amino acid 150-1270 of cardiac isoform has a striking homology to amino acid 47-1132 of chicken skeletal isoform. The homology gap corresponding to the amino acid insertion (residue 682-711) in domain 6 of cardiac C-protein is indicated by the bold arrows. About $100 \mathrm{NH}_{2}$-terminal amino acids show strong homology to two IgG-like domains (domains 3 and 4 ) of skeletal C-protein (small arrows, * indicating domain 3,** indicating domain 4). (B) Schematic structure of cardiac C-protein and chick skeletal C-protein consisting of two repeated motifs, IgG-like and Fn-like domains. Mouse cardiac C-protein domain 2-11 corresponded to chick skeletal isoform domain 1-10. (C) Alignment analysis of amino acid sequence of individual domain of murine heart $\mathrm{C}$-protein $(M H-C P)$. Numbers 1-11 on the left indicate positions in the C-protein deduced amino acid sequence. Alignment was done by inspection. IgG-like motifs of C-protein are compared with chicken neural cell adhesion molecule ( $N$-CAM 3) (41) and a consensus for the immunoglobulin C-2 set domains (CONSENSUS) (40), Fn-like domains to human Fn type III repeat (HU-FN III) (42), and a consensus for the Fn type III domains (CONSENSUS) (43).

fast isoform [37], 1,138 in human slow isoform [38]). As shown in Fig. 6, $A$ and $B$, amino acid 150-1270 of cardiac isoform had striking homology to amino acid 47-1132 of chicken skeletal isoform using the HARRPLOT program (GENETYX Software Development Co.) (39). However, there was a homology gap between 682 and 711 amino acids of cardiac isoform, indicating a 30-amino acid insertion in one of the IgG-like domains, repeat 6. About $100 \mathrm{NH}_{2}$-terminal amino acids showed strong homology to two IgG-like domains of skeletal isoform, domain 3 (amino acids 354-444) and domain 4 (amino acids 445-550). This additional immunoglobu- lin-like domain has four of nine IgG consensus sequences (40) and internal homology to cardiac isoforms domains 3,4 , and 5 with 26,26 , and $23 \%$ identity, respectively.

Fig. $6 C$ shows the alignment of amino acid sequence of individual domain. IgG-like motifs of C-protein are compared with chick neural cell adhesion molecule (41) and a consensus for the Ig C2 set domain (40). Fibronectin (Fn)-like domains are compared with human Fn type III repeats (42) and a consensus for the Fn type III domain (43). In the eight IgG-like domains shown in Fig. $6 C$, internal homology was seen between 17 (domains 2 and 6, and 4 and 6) and 29\% (domains 


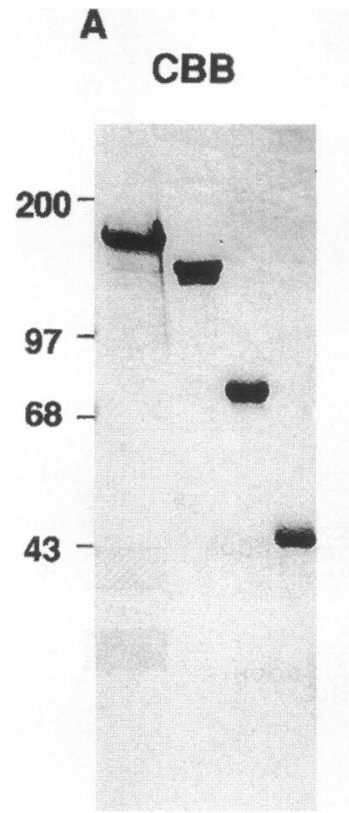

$\begin{array}{llll}1 & 2 & 3 & 4\end{array}$
B

\section{Auto-Ab}

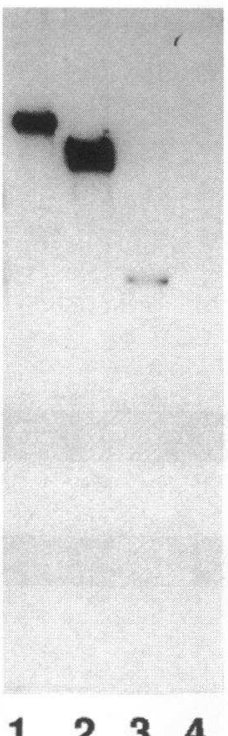

C

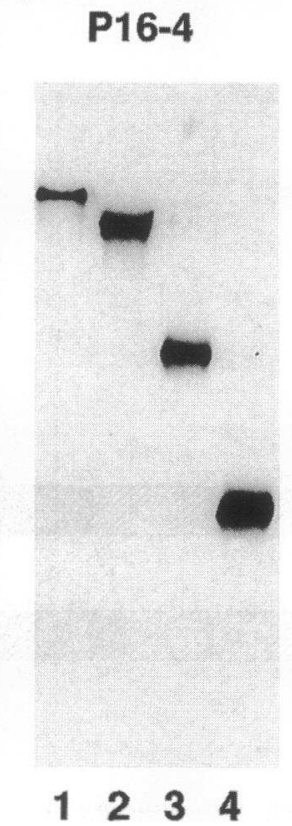

D

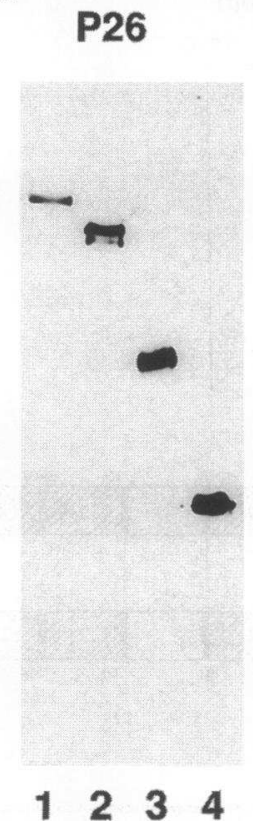

E

\section{MBP}

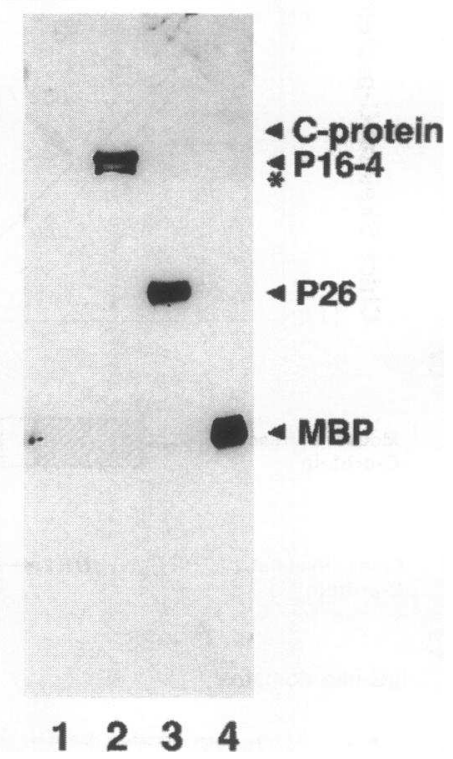

Figure 7. Immunoblot analysis of the fusion proteins. (A) Coomassie blue-stained gel of C-protein (lane 1), P16-4 (lane 2), P26 (lane 3), and MBP (lane 4). Accompanying immunoblots with the autoantibody ( $\mathrm{Ab} 1)$ from mice immunized heart homogenate $(B)$, from P16-4 immunized mice $(C)$, P26 immunized mice $(D)$, and MBP immunized mice $(E)$. The autoantibody $(A b 1)$ reacts to P16-4 $(B$, lane 2$)$ and reacts weakly to $\mathrm{P} 26(B$, lane 3), but not to MBP $(B$, lane 4$)$. The two autoantibodies against P16-4 and P26 reacted with C-protein $(C$ and $D$, lane 1$)$. These autoantibodies from fusion protein-immunized mice $(C-E)$ react with all the fusion proteins (P16-4, P26, and MBP) by the crossreaction to MBP. The asterisk indicates degradation form of P16-4.

3 and 4) identity. Only domain 11 conserves a pair of cysteine in all 3 isoforms of C-protein, at this part the C-protein bound to myosin (37). In the three Fn-like domains, internal homology was similar to that of IgG-like domains between 19 (domains 7 and 10 ) and $26 \%$ (domains 8 and 10 ) identity.

Partial characterization of the antigenic peptide. We generated two fusion proteins, P26 (amino acid residue; 945-1270), and P16-4 (amino acid residue; 205-916) encoded by part of the cDNA, C26, and the PstI-PstI fragment of clone C16, respectively (Fig. $4 B$ ). A full-length fusion protein could not be used as the antigen due to its low expression level and degradation in $E$. coli. As shown in Fig. 7 B, both fusion proteins P16-4 and P26 were recognized by the autoantibody (Ab 1). The stronger reactivity to P16-4 suggested that this fragment of $\mathrm{C}$-protein has an autoantibody ( $\mathrm{Ab} 1$ ) recognition site. Thus we immunized purified fusion proteins and MBP to examine the pathogenicity of P16-4. As expected, P16-4 induced myocarditis in all of the immunized SMA mice at the dose of 100 $\mu \mathrm{g}$ and in $66 \%$ at the dose of $50 \mu \mathrm{g}$, whereas neither 100 nor $50 \mu \mathrm{g}$ of P26 induced myocarditis (Fig. 8, Table II). In addition, both P16-4 and P26 produced antibodies against C-protein (Fig. $7, C$ and $D$, lane 1 ); the former reacted strongly to C-protein. These findings suggested that the dominant immunogenic epitope exists in residues 205-916. As a control experiment, MBP alone did not produce the antibody against C-protein (Fig. $7 \mathrm{E}$, lane 1) nor did it induce myocarditis (Table II). To confirm the antigenicity of this peptide 205-916 in other strains of mouse, we immunized DBA/1J $\left(H-2^{q}\right), D B A / 2 J\left(H-2^{d}\right)$, BALB/c $\left(\mathrm{H}_{-2}{ }^{\mathrm{d}}\right), \mathrm{C} 57 \mathrm{BL} / 6\left(\mathrm{H}-2^{\mathrm{b}}\right), \mathrm{O} 20 / \mathrm{A}\left(\mathrm{H}-2^{\mathrm{pz} 1}\right), \mathrm{SJL}(\mathrm{H}-$ $\left.2^{s}\right), A / J\left(H-2^{a}\right), A K R / J\left(H-2^{k}\right)$, and $\mathrm{C} 3 H / H e\left(H-2^{k}\right)$ with
$100 \mu \mathrm{g}$ of P16-4 which effectively induced myocarditis in SMA mice. All immunized DBA/1J, O20/A, and SJL mice developed myocarditis, whereas only a few C57BL/6 (25\%), BALB/ c $(16 \%), \mathrm{C} 3 \mathrm{H} / \mathrm{He}(16 \%)$, and no DBA/2J, A/J, or AKR/J developed myocarditis (Table II).

Demonstration of C-protein-reactive autoantibodies in DCM patients. We analyzed sera from 16 patients diagnosed with DCM, as well as sera from 83 normal individuals by immunoblotting against human heart homogenate (Fig. 9). No control sera (Fig. $9 \mathrm{~B}$ ) and 2 of $16 \mathrm{DCM}$ sera (Fig. $9 \mathrm{~A}$, lanes 9 and 12) reacted specifically to the protein which was $\sim 150 \mathrm{kD}$. We confirmed that this $150-\mathrm{kD}$ band was C-protein because these two sera reacted against the purified human cardiac $\mathbf{C}$ protein (Fig. $9 C$, lane 2). Therefore, we conclude that 2 of 16 sera had an antibody to C-protein. In normal control sera, even though no sera preferentially recognized the $150-\mathrm{kD}$ protein, we found a high incidence of autoantibodies against several human cardiac proteins including myosin, as Neumann et al. (7) reported previously.

\section{Discussion}

In this study, cardiac C-protein was found to be a dominant antigen among many types of cardiac proteins and to induce autoimmune myocarditis under experimental conditions. This conclusion is substantiated by the following experimental findings: ( $a$ ) the autoantibody produced by the myocarditis-induced mouse specifically reacted to the $150-\mathrm{kD}$ protein (C-protein) in spite of immunized whole cardiac tissue homogenate; $(b)$ purified C-protein induced myocarditis; and $(c)$ recombinant 


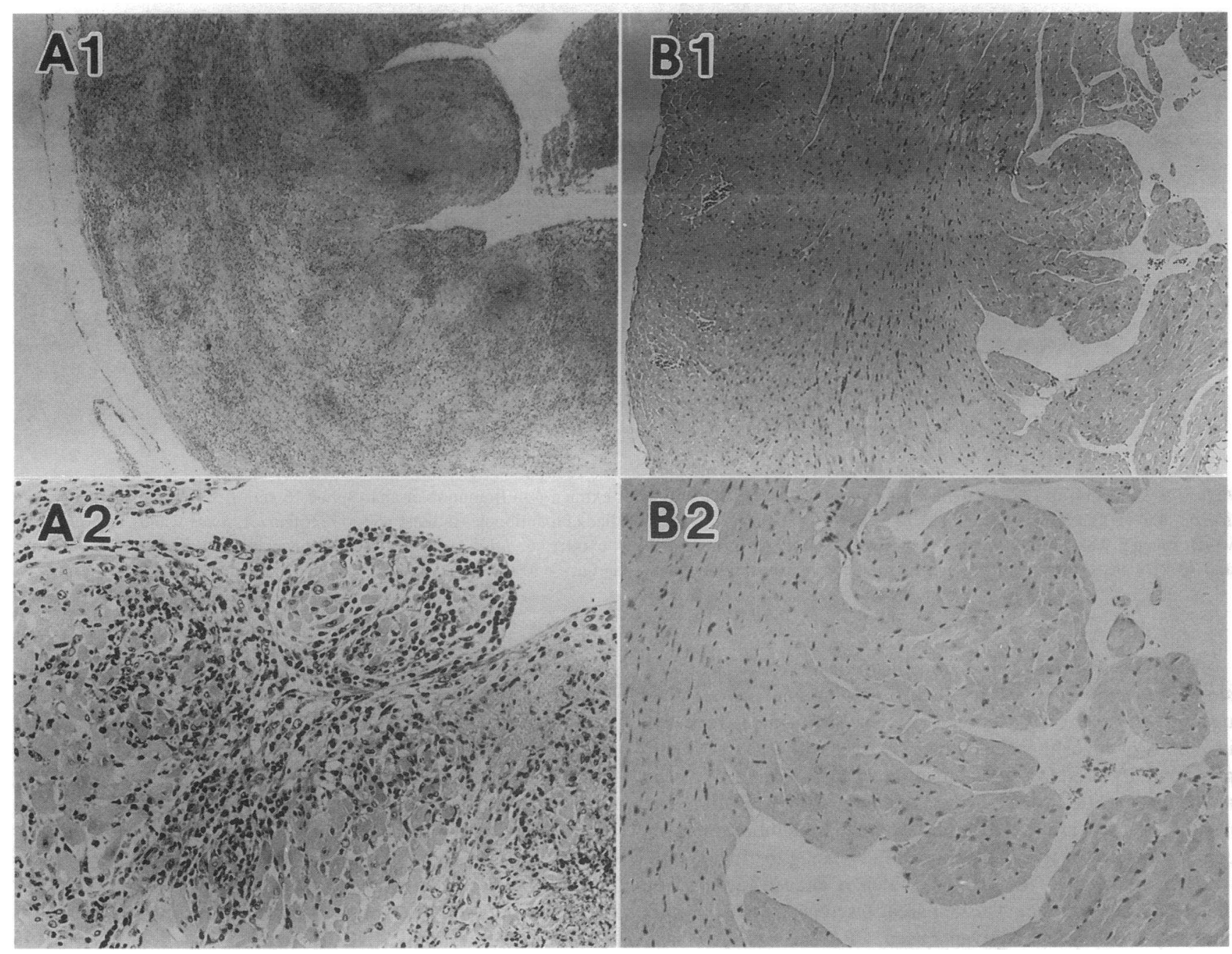

Figure 8. Autoimmune myocarditis induced by the repeated injections of recombinant proteins with KO3 LPS. ( $A 1$ and $A 2)$ P16-4 induced severe inflammatory responses in the heart. No inflammatory changes were observed in mice immunized with P26 ( $B 1$ and $B 2$ ) (hematoxylin and eosin staining).

Table II. Induction of Murine Autoimmune Myocarditis with Fusion Proteins*

\begin{tabular}{cllrr}
\hline Experiment & Mouse & Immunogen & $\begin{array}{r}\text { Antigen } \\
\text { dose } \times \text { times }\end{array}$ & $\begin{array}{r}\text { Induction of } \\
\text { myocarditis }\end{array}$ \\
\hline 1 & SMA & P16-4 (residue (205-916) & $100 \mu \mathrm{g} \times 4$ & $100 \%(6 / 6)$ \\
& & & $50 \mu \mathrm{g} \times 5$ & $66 \%(2 / 3)$ \\
& & P26 (residue 945-1270) & $100 \mu \mathrm{g} \times 5$ & $0 \%(0 / 3)$ \\
& & & $50 \mu \mathrm{g} \times 5$ & $0 \%(0 / 3)$ \\
& & MBP & $100 \mu \mathrm{g} \times 5$ & $0 \%(0 / 6)$ \\
& & & $50 \mu \mathrm{g} \times 5$ & $0 \%(0 / 6)$ \\
& & & $100 \mu \mathrm{g} \times 5$ & $100 \%(6 / 6)$ \\
& DBA/1J & P16-4 (residue 205-916) & $100 \%(6 / 6)$ \\
& SJL & & & $100 \%(5 / 5)$ \\
& O20/A & & & $0 \%(0 / 3)$ \\
A/J & & & $0 \%(0 / 3)$ \\
AKR/J & & & $16 \%(1 / 6)$ \\
Balb/c & & & $16 \%(1 / 6)$ \\
C3H/He & & & $25 \%(1 / 4)$ \\
C57BL/6 & & & $0 \%(0 / 3)$ \\
DBA/2J & & &
\end{tabular}

* Antigens mixed with $100 \mu \mathrm{g} \mathrm{KO3} \mathrm{LPS} \mathrm{were} \mathrm{injected} \mathrm{at} \mathrm{4-wk} \mathrm{intervals.}$ cardiac C-protein (amino acid residue 205-916) effectively produced myocarditis in some mice strains including SMA, DBA/1J, SJL, and O20/A, but not in A/J, AKR/J, or DBA/2J mice strains.

In spite of the prevalence of autoimmune diseases, a limited number of autoantigens have been identified to induce disease in experimental animal models, e.g., thyroglobulin for chronic thyroiditis (44), acetylcholine receptor for myasthenia graves (45), uveal S antigen for uveitis (46), myelin basic protein for multiple sclerosis (47), type II collagen for synovitis (48), and gp330 and 44-kD complex for Heymann nephritis $(49,50)$. These autoantigens must be identified for the development of disease-specific therapeutic strategies, ultimately to human autoimmune disease $(51,52)$. The knowledge of the structure of the antigenic epitopes enabled us to use synthetic peptides that mimic pathogenic epitopes $(53,54)$. The present experimental findings showing that $\mathrm{C}$-protein is an important antigen in the development of autoimmune myocarditis, and the partial identification of the pathogenic amino acid motif should help in the development of therapeutic strategies through the use of our myocarditis model. 
A

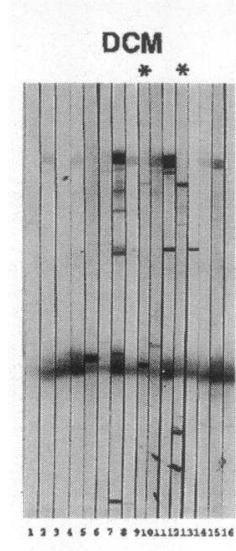

B

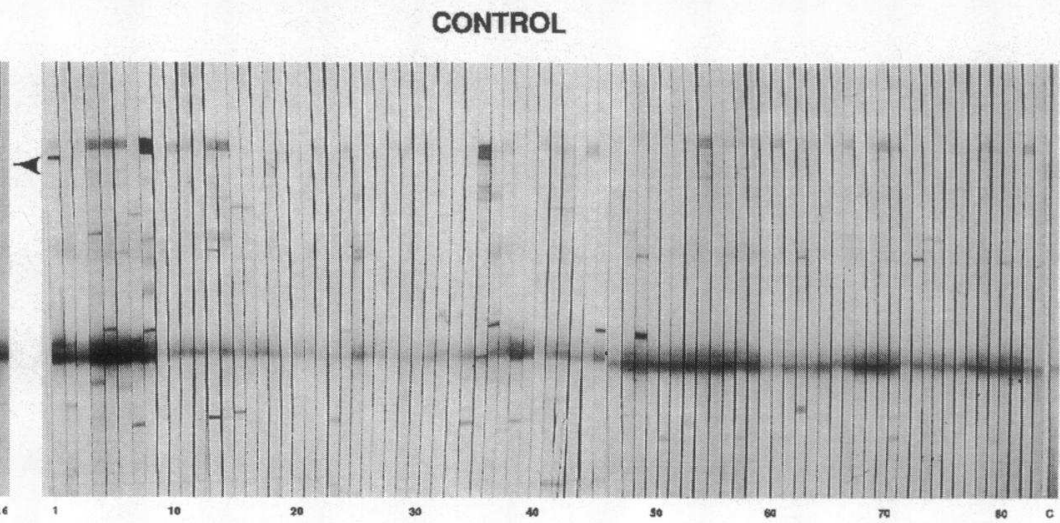

C

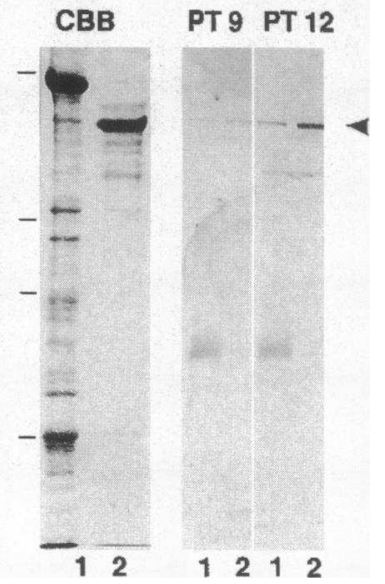

Figure 9. Detection of DCM patients' autoantibodies against human heart extract. $(A)$ Immunoblot analysis of 16 sera from DCM patients (lanes 1-16), and (B) 83 normal sera (lanes 1-83). Two patients (PT 9 and 12) had autoantibodies against 150-kD protein (A, lanes 9 and 12, asterisks), which reacted with purified human C-protein $(C$, lane 2$)$, as well as heart extract $(C$, lane 1$)$. Positions of molecular mass markers $(200,97,68$, and $43 \mathrm{kD}$ ) are shown. Anti-human IgG reacted nonspecifically to the band at $\sim 50 \mathrm{kD}(B$, lane $C)$.

The present findings conflict with an earlier report that myosin is the major antigen producing autoimmune myocarditis under $\mathrm{H}-2$ genetic restriction (12). In SMA mice, repeated injections of myosin-enriched heart extract with KO3 LPS still preferentially produced the autoantibody to C-protein. We also noted that purified cardiac myosin mixed with KO3 LPS did not induce myocarditis (data not shown). In addition, myosin contamination was avoided completely by using the fusion protein expressed in E. coli, P16-4, which is encoded by part of the cDNA of C-protein. This apparent discrepancy is explained partly by the different adjuvants used, CFA and LPS $(12,55)$. The other difference is observed in the responder strain. The $\mathrm{A} / \mathrm{J}$ background is a high responder to myosin-induced myocarditis irrespective of the H-2 haplotype (12), and to CB3-induced myocarditis $(56,57)$. CB3-induced myocarditis, which might further trigger autoimmune reactions against myosin by a molecular mimicry mechanism, has been suggested to be a possible underlying pathogenesis of $\operatorname{DCM}(58,59)$. In the present study, we suggest that the autoimmune triggering mechanism in Cprotein-induced myocarditis may differ from a CB3-triggered or myosin-induced mechanism because: $(a)$ crossreactive epitopes between CB3 and C-protein have not been reported; and (b) contrary to the previous results that $\mathrm{A} / \mathrm{J}, \mathrm{C} 3 \mathrm{H} / \mathrm{He}, \mathrm{Balb} /$ c, DBA/ 2 strains have a high susceptibility to CB3 $(56,57)$, the C-protein residue 205-916 hardly induced myocarditis in these strains in the present experiment. The limitation of our approach is that we used a part of the C-protein, $60 \%$ of full length, for immunization; a full-length fusion protein could not be used as the antigen because of its low expression level and degradation in $E$. coli.

Further, it is of importance to attempt to explain the clear strain differences in the response to the $\mathrm{C}$-protein mixed with LPS. SMA, DBA/1J $\left(\mathrm{H}-2^{\mathrm{q}}\right)$, SJL $\left(\mathrm{H}-2^{\mathrm{s}}\right)$, and O20/A (H-2 $\left.{ }^{\mathrm{pz} 1}\right)$ are high responders, whereas DBA/2J $\left(\mathrm{H}-2^{\mathrm{d}}\right), \mathrm{BALB} / \mathrm{c}(\mathrm{H}-$ $\left.2^{\mathrm{d}}\right), \mathrm{C} 57 \mathrm{BL} / 6\left(\mathrm{H}-2^{\mathrm{b}}\right), \mathrm{A} / \mathrm{J}\left(\mathrm{H}-2^{\mathrm{a}}\right), \mathrm{AKR} / \mathrm{J}\left(\mathrm{H}-2^{\mathrm{k}}\right)$, and C3H/ $\mathrm{He}\left(\mathrm{H}-2^{k}\right)$ are poor responders. One explanation is the differing sensitivity to adjuvant KO3 LPS and, in part, the different reper- toire of helper T cell receptor (TCR) used (60). However, the most important explanation of the association between the autoimmune disease and MHC alleles in human and animal models is that different peptides bind to different MHC II antigens; the triad formation between antigen, MHC, and TCR is critical to the activation of $\mathrm{T}$ cells and further immune responses (60).

The positions of the amino acid sequence responsible for the induction of myocarditis can be hypothesized. Little is known about the consensus sequence of amino acid motifs which bind to murine MHC II; only those for $I-A^{b}, I-E^{b}(61)$, $I_{-} A^{d}(62)$, and $I-A^{s}(63)$ have been reported. Here, in SJL mice, which express $\mathrm{I}^{\mathrm{s}} \mathrm{A}^{\mathrm{s}}$, myocarditis was induced in $100 \%$ with fusion protein P16-4. C-protein has the consensus sequence which binds to I-A ${ }^{s}(63)$, VSXXXXR/H sequence ( $X$ can be any amino acid) derived from the transferrin receptor:

$$
\begin{array}{lcc}
\text { C-protein } & \text { FKCEVSDENVRGVWLK } & (560-575) \\
& * * * & * \\
\text { Transferrin receptor } & \text { KPTEVSGKLVHANFGT } & (203-218) .
\end{array}
$$

The pathogenic epitopes on the P16-4 in these four different strains remain to be determined.

Although myocardial cells are composed of many types of proteins, the mechanism by which the $\mathrm{C}$-protein induces autoimmune myocarditis remains unknown. C-protein is one of the major constituent proteins necessary to compete with natural antigens such as invariant chain and MHC to obtain the position at the MHC antigen-binding site $(64,65)$. Further, examination of the structure of the C-protein leads to some speculation on its role in the autoimmune reaction. $\mathrm{C}$-protein is an intracellular member of the immunoglobulin superfamily (36-38). IgG-like domains are conserved in most cell-surface immune recognition molecules (40), and also TCR and MHC class II have this domain (40). Recently, the peptides of recycled membrane proteins, class II HLA and invariant chain, have been shown to be major self-antigens which are presented by class II molecules 
(61-63, 66, 67). However the HLA-binding motifs are located in the variable domain of this structure, not in this constant IgG-like domain $(61-63,66,67)$. It may be questioned whether or not these IgG-like conformations work with each other at the cell surface similar to the directly bound MHC-TCR like superantigen (68). These questions remain to be answered.

Finally, the possible involvement of C-protein-triggered autoimmune myocarditis in DCM must be discussed. In this study, it was found that the sera of 2 DCM patients of the 16 preferentially recognized the C-protein, as based on the results of immunoblotting against whole cardiac proteins. On the other hand, none of the control sera specifically reacted to the Cprotein. In spite of numerous studies, the pathogenesis of DCM still remains obscure, and treatment is generally cardiac transplantation. Considering the DCM is a pluricausal disease (3) and 2 of 16 patients' sera specifically recognized the C-protein, we hope this experimental model will lead to the elucidation of one of the possible causes of this disease. Also, if autoimmune reaction occurring by molecular mimicry between $\mathrm{CB} 3$ and myosin or C-protein is one of the causes of DCM, it would be of interest to test the changes in autoantibody production in the chronic stage of infectious myocarditis. To clarify this point, sera from patients with acute and chronic phase myocarditis would be needed.

\section{Acknowledgments}

We thank T. Obinata for FC-18 mAb; M. Ohta, N. Arakawa, H. Ito, S. Naito, Sa. Tsukita, S. Yonemura, A. Nagafuchi, N. Funayama, K. Takeuchi, and N. Sato for technical help and suggestions; J. Asai, M. Ito, and M. Ohbayashi for histological evaluation of hearts and supply of human heart tissue; J. Kito and A. Takei for supplying the mice; Toyota Motor Health Insurance Society for normal control sera; Fujita Health University Hospital, Meitetsu Hospital, Nagoya University Hospital, Nagoya Ekisaikai Hospital, Nakatsugawa City Hospital, Nishio City Hospital, Tokoname City Hospital, Toukai-chuo Hospital, Touno Hospital, and Toyota Memorial Hospital for the sera of DCM patients; and I. Nakashima and Y. Yoshikai for comments and evaluation of this manuscript. T. Obinata et al. (69) reported the cloning of a cardiac isoform of Cprotein from chick heart at the Annual Meeting of Japan Society for Cell Biology.

\section{References}

1. Goodwin, J. F. 1970. Congestive and hypertrophic cardiomyopathies. Lancet. i:731-739.

2. Goodwin, J. F. 1982. The frontiers of cardiomyopathy. Br. Heart J. 48:118.

3. Manolio, T. A., K. L. Baughman, R. Rodeheffer, T. A. Pearson, J. D. Bristow, V. V. Michels, W. H. Abelmann, and W. R. Harlan. 1992. Prevalence and etiology of idiopathic dilated cardiomyopathy (summary of National Heart, Lung, and Blood Institute workshop). Am. J. Cardiol. 89:1458-1466.

4. Abelmann, W. H., and B. H. Lorell. 1989. The challenge of cardiomyopathy. J. Am. Coll. Cardiol. 13:1219-1239.

5. Schultheiss, H. P., and H. D. Bolte. 1985. Immunological analysis of autoantibodies against the adenine nucleotide translocator in dilated cardiomyopathy. J. Mol. Cell. Cardiol. 17:603-617.

6. Wolff, P. G., U. Kühl, and H. P. Schultheiss. 1989. Laminin distribution and autoantibodies to laminin in dilated cardiomyopathy and myocarditis. Am. Heart J. 117:1303-1309.

7. Neumann, D. A., C. L. Burek, K. L. Baughman, N. R. Rose, and A. H. Herskowitz. 1990. Circulating heart-reactive antibodies in patients with myocarditis or cardiomyopathy. J. Am. Coll. Cardiol. 16:839-846.

8. Caforio, A. L. P., M. Grazzini, J. M. Mann, P. J. Keeling, G. F. Bottazzo, W. J. McKenna, and S. Shiaffino. 1992. Identification of $\alpha$-and $\beta$ - cardiac myosin heavy chain isoforms as major autoantigens in dilated cardiomyopathy. Circulation. 85:1734-1742.
9. Caforio, A. L. P., J. T. Stewart, E. Bonifacio, M. Burke, M. J. Davies, W. J. McKenna, and G. F. Bottazzo. 1990. Inappropriate major histocompatibility complex expression on cardiac tissue in dilated cardiomyopathy. Relevance for autoimmunity? J. Autoimmun. 3:187-200.

10. Carlquist, J. F., R. L. Menlove, M. B. Murray, J. B. O'Connell, and J. L. Anderson. 1991. HLA class II (DR and DQ) antigen associations in idiopathic dilated cardiomyopathy. Validation study and meta-analysis of published HLA association studies. Circulation. 83:515-522.

11. Nishi, H., A. Kimura, S. Fukuta, R. Kusukawa, K. Kawamura, Y. Nimura, M. Nagano, H. Yasuda, C. Kawai, T. Sugimoto, et al. 1992. Genetic analysis of dilated cardiomyopathy: HLA and immunoglobulin genes may confer susceptability. Jpn. Circ. J. 56:1054-1061.

12. Neu, N., N. R. Rose, K. W. Beisel, A. Herskowitz, G. G. Glass, and S. W. Craig. 1987. Cardiac myosin induces myocarditis in genetically predisposed mice. J. Immunol. 139:3630-3636.

13. Izumi, T., B. Maish, and K. Kochsiek. 1987. Experimental murine myocarditis after immunization with cardiac membranous proteins. Eur. Heart J. 8(Suppl. J):419-424.

14. Kaplan, M. H., and J. M. Craig. 1963. Immunologic studies of heart tissue. VI. Cardiac lesions in rabbits associated with autoantibodies to heart induced by immunization with heterologous heart. J. Immunol. 90:725-733.

15. Fukuta, S., S. Iwamoto, Y. Kimura, K. Yamakawa, K. Wada, R. Kusukawa, and M. Honda. 1980. Experimental myocarditis. I. Cardiac lesions in rats induced by immunization with homologous heart extracts. Jpn. Circ. J. 44:833-837.

16. Nakashima, I., T. Yokochi, N. Kato, and J. Asai. 1977. Microbial adjuvant and autoimmunity. II. Production of lesions in mice immunized with syngeneic tissue extracts together with the capsular polysaccharide of Klebsiella pneumoniae. Microbiol. Immunol. 21:279-288.

17. Yokochi, T., I. Nakashima, N. Kato, and J. Asai. 1978. Microbial adjuvant and autoimmunity. III. Histological studies of development of experimental thyroiditis in mice immunized with syngeneic thyroid extracts together with the capsular polysaccharide of Klebsiella pneumoniae. Microbiol. Immunol. 22:619630.

18. Yamaki, K., M. Ohta, I. Nakashima, A. Noda, J. Asai, and N. Kato. 1980. Microbial adjuvant and autoimmunity. IV. Production of lesions in the exocrine pancreas of mice by repeated injection of syngeneic pancreatic extract together with the capsular polysaccharide of Klebsiella pneumoniae. Microbiol. Immunol. 24:945-956.

19. Kuriki, J., H. Murakami, S. Kakamu, N. Sakamoto, T. Yokochi, I. Nakashima, and N. Kato. 1983. Experimental autoimmune hepatitis in mice after immunization with syngeneic liver protein together with the capsular polysaccharide of Klebsiella pneumoniae. Gastroenterology. 84:596-603.

20. Kato, T., H. Yamada, T. Yokochi, I. Nakashima, and N. Kato. 1984. Experimental autoimmune hemolytic anemia in mice induced by repeated immunization with ultrasonicated syngeneic erythrocytes together with Klebsiella $\mathrm{O} 3$ lipopolysaccharide. Acta Haematol. Jpn. 47:838-845.

21. Yokochi, T., H. Ikeda, Y. Inoue, Y. Kimura, H. Ito, Y. Fujii, and N. Kato. 1990. Characterization of autoantigens relevant to experimental autoimmune orchitis (EAO) in mice immunized with a mixture of syngeneic testis homogenate and Klebsiella $\mathrm{O} 3$ lipopolysaccharide. Am. J. Reprod. Immunol. 22:42-48.

22. Iwase, K., Y. Fujii, I. Nakashima, N. Kato, Y. Fujino, H. Kawashima, and M. Mochizuki. 1990. A new method for induction of experimental autoimmune uveoretinitis (EAU) in mice. Curr. Eye Res. 9:207-216.

23. Fujii, Y., N. Kato, J. Kito, J: Asai, and T. Yokochi. 1992. Experimental autoimmune adrenalitis: a murine model for Addison's disease. Autoimmunity. 12:47-52.

24. Kato, N., Y. Fujii, N. Agata, N. Kido, M. Ohta, S. Naito, and T. Yokochi. 1993. Experimental murine model for autoimmune myocarditis using Klebsiella pneumoniae $\mathrm{O} 3$ lipopolysaccharide as a potent immunological adjuvant. Autoimmunity. 14:231-236.

25. Neu, N., S. W. Craig, N. R. Rose, F. Alvarez, and K. W. Beisel. 1987. Coxsackie virus induced myocarditis in mice: cardiac myosin autoantibodies do not cross-react with the virus. Clin. Exp. Immunol. 69:566-574.

26. Hartzell, H. C., and D. B. Glass. 1984. Phosphorylation of purified cardiac muscle $\mathrm{C}$-protein by purified cAMP-dependent and endogenous $\mathrm{Ca}^{2+}$-calmodulindependent protein kinases. J. Biol. Chem. 259:15587-15596.

27. Nakashima, I., T. Kobayashi, and N. Kato. 1971. Alterations in the antibody response to bovine serum albumin by capsular polysaccharide of Klebsiella pneumoniae. J. Immunol. 107:1112-1121.

28. Ohta, M., M. Mori, T. Hasegawa, T. Nagase, I. Nakashima, and N. Kato. 1981. Further studies of the polysaccharide of Klebsiella pneumoniae possessing strong adjuvanticity. I. Production of the adjuvant polysaccharide by noncapsulated mutant. Microbiol. Immunol. 25:939-948.

29. Laemmli, U. K. 1970. Cleavage of structural proteins during assembly of the head of bacteriophage $T_{4}$. Nature (Lond.). 227:680-685.

30. Huynh, T. U., R. A. Young, and R. W. Davis. 1985. Construction and screening cDNA libraries in $\lambda$ gt 10 and $\lambda$ gt11. In DNA Cloning Techniques: A 
Practical Approach. Vol. 1. D. M. Glover, editor. Oxford University/IRL Press. Oxford. 49-78.

31. Offer, G., C. Moos, and R. Starr. 1973. A new protein of the thick filaments of vertebrate skeletal myofibrils. J. Mol. Biol. 74:653-676.

32. Murakami, U., K. Uchida, and T. Hiratsuka. 1976. Cardiac myosin from pig heart ventricle. J. Biochem. 80:611-619.

33. Yamamoto, K., and C. Moos. 1983. The C-proteins of rabbit red, white, and cardiac muscles. J. Biol. Chem. 258:8395-8401.

34. Hartzell, H. C., and W. S. Sale. 1985. Structure of C-protein purified from cardiac muscle. J. Cell Biol. 100:208-215.

35. Shinagawa, Y., H. Abe, K. Saiga, and T. Obinata. 1993. Increased expression of cofilin in denervated chicken skeletal muscle. Zool. Sci. (Tokyo). 10:611618.

36. Einheber, S., and D. A. Fischman. 1990. Isolation and characterization of cDNA clone encoding avian muscle C-protein: an intracellular member of the immunoglobulin superfamily. Proc. Natl. Acad. Sci. USA. 87:2157-2161.

37. Okagaki, T., F. E. Weber, D. A. Fischman, K. T. Vaughan, T. Mikawa, and F. C. Reinach. 1993. The major myosin-binding domain of skeletal muscle MyBP-C (C protein) resides in the $\mathrm{COOH}$-terminal, immunoglobulin $\mathrm{C} 2$ motif. J. Cell Biol. 123:619-626.

38. Fürst, D. O., U. Vinkemeier, and K. Weber. 1992. Mammalian skeletal muscle C-protein: purification from bovine muscle, binding to titin and the characterization of a full-length human cDNA. J. Cell Sci. 102:769-778.

39. Staden, R. 1982. An interactive graphics program for comparing and aligning nucleic acid and amino acid sequences. Nucleic Acids Res. 10:29512961.

40. Williams, A. F., and A. N. Barclay. 1988. The immunoglobulin superfamily-domains for cell surface recognition. Annu. Rev. Immunol. 6:381-405.

41. Cunningham, B. A., J. J. Hemperly, B. A. Murray, E. A. Prediger, R. Brackenbury, and G. M. Edelman. 1987. Neural cell adhesion molecule: structure, immunoglobulin-like domains, cell surface modulation, and alternative RNA splicing. Science (Wash. DC). 236:799-805.

42. Kornblihtt, A. R., K. Umezawa, K. Vibe-Pedersen, and F. E. Baralle 1985. Primary structure of human fibronectin: different splicing may generate at least 10 polypeptides from a single gene. EMBO (Eur. Mol. Biol. Organ.) J. 4:1755-1759.

43. Hynes, R. 1985. Molecular biology of fibronectin. Annu. Rev. Cell Biol. $1: 67-90$

44. Kong, Y. M., C. S. David, A. A. Giraldo, M. Elrehewy, and N. R. Rose 1979. Regulation of autoimmune response to mouse thyroglobulin: influence of H-2D-end genes. J. Immunol. 123:15-18.

45. Lindstrom, J. M. B. L. Einarson, V. A Lennon, and M. E. Seybold. 1976. Pathological mechanisms in experimental autoimmune myasthenia gravis. I. Immunogenecity of syngeneic muscle acetylcholine receptor and quantitative extraction of receptor and antibody-receptor complexes from muscles of rats with experimental autoimmune myasthenia gravis. J. Exp. Med. 144:726-738.

46. Wacker, W. B., L. A. Donoso, D. M. Kalsow, L. A. Yankeelov, and D. T. Organisciak. 1977. Experimental allergic uveitis. Isolation, characterization, and localization of a soluble uveitopathogenic antigen from bovine retina. J. Immunol. 119:1949-1958.

47. McFarlein, D. E., S. E. Blank, R. F. Kiebler, S. McKneally, and R. Shapira. 1973. Experimental allergic encephalomyelitis in the rat: response to encephalitoogenic proteins and peptides. Science (Wash. DC). 179:478-480.

48. Courtenay, J. S., M. J. Dallman, A. D. Dayan, A. Martin, and B. Mosedale. 1990. Immunization against heterologous type II collagen induces arthritis in mice. Nature (Lond.). 283:666-668

49. Kerjaschki, D., and M. G. Farquhar. 1982. The pathogenic antigen of Heymann nephritis is a membrane glycoprotein of the renal proximal tubule brush border. Proc. Natl. Acad. Sci. USA. 79:5557-5561.

50. Kerjaschki, D., R. Ullrich, K. Diem, S. Pietromonaco, R. A. Orlando, and
M. G. Farquhar. 1992. Identification of a pathologenic epitope involved in initiation of Heymann nephritis. Proc. Natl. Acad. Sci. USA. 89:11179-11183.

51. Trentham, D. E., R. A. Dynesius-Trentham, E. J. Orav, D. Combitchi, C. Lorenzo, K. L. Sewell, D. A. Hafler, and H. L. Weiner. 1993. Effects of oral administration of type II collagen on rheumatoid arthritis. Science (Wash. DC.). 261:1727-1730.

52. Weiner, H. L., G. A. Mackin, M. Matsui, E. J. Orav, S. J. Khoury, D. M. Dawson, and D. A. Hafler. 1993. Double-blind pilot trial of oral tolerization with myelin antigens in multiple sclerosis. Science (Wash. DC). 259:1321-1324.

53. Kumar, V., J. L. Urban, S. J. Horvath, and L. Hood. 1990. Amino acid variations at a single residue in an autoimmune peptide profoundly affect its properties: T-cell activation, major histocompatibility complex binding, and ability to block experimental allergic encephalomyelitis. Proc. Natl. Acad. Sci. USA. 87:1337-1341.

54. Wraith, D. C. D. E Smilek, D. J. Mitchell, L. Steinman, and H. O. McDevitt. 1989. Antigen recognition in autoimmune encephalomyelitis and the potential for peptide-mediated immunotherapy. Cell. 59:247-255.

55. Lane, J. R., D. A. Neumann, A. Lafond-Walker, A. Herskowitz, and N. R. Rose. 1992. Interleukin 1 or tumor necrosis factor can promote Coxsackie B3induced myocarditis in resistant B10.A mice. J. Exp. Med. 175:1123-1129.

56. Neu, N., K. W. Beisel, M. D. Traystman, N. R. Rose, and S. W. Craig. 1987. Autoantibodies specific for the cardiac myosin isoform are found in mice susceptible to Coxsackie virus B3-induced myocarditis. J. Immunol. 138:24882492

57. Lawrence, H. C., C. J. Gauntt, and B. M. McManus. 1991. Differential effects of myocarditic variants of Coxsackie virus B3 in inbred mice. Lab. Invest. 64:55-64.

58. Noel, R. R., D. A. Neumann, and A. Herskowitz. 1991. Autoimmune myocarditis: concepts and questions. Immunol. Today 12:253-255.

59. Cunningham, M. W. S. M. Antone, J. M. Gulizia, B. M. McManus, V. A Fischetti, and C. J. Gauntt. 1992. Cytotoxic and viral neutralizing antibodies crossreact with streptococcal M protein, enteroviruses, and human cardiac myosin. Proc. Natl. Acad. Sci. USA. 89:1320-1324.

60. Wraith, D. C., H. O. McDevitt, L. Steinman, and H. Acha-Orbea. 1989. $\mathrm{T}$-cell recognition as the target for immune intervention in autoimmune disease. Cell. 57:709-715.

61. Rudensky, A. Y., P. P. Hurlburt, S. C. Hong, A. Barlow, and C. A. Janeway. 1991. Sequence analysis of peptides bound to MHC class II molecules. Nature (Lond.). 353:622-627.

62. Hunt, D. F., H. Michel, T. A. Dickinson, J. Shabanowitz, A. L. Cox, K. Sakaguchi, E. Appella, H. M. Grey, and A. Sette. 1992. Peptides presented to the immune system by the murine class II major histocompatibility complex molecule I-A. Science (Wash. DC). 256:1817-1820.

63. Rudensky, A. Y., P. P. Hurlburt, B. K. Ai-Ramadi, J. Rothbard, and C. A. Janeway. 1992. Truncation variants of peptides isolated from MHC class II molecules suggest sequence motifs. Nature (Lond.). 359:429-431.

64. Demotz, S., H. M. Grey, and A. Sette. 1990. The minimal number of class II MHC-antigen complexes needed for T cell activation. Science (Wash. DC). 249:1028-1030.

65. Harding, C. V., and E. R. Unanue. 1990. Quantification of antigen presenting cell MHC class II/peptide complex necessary for T-cell stimulation. $\mathrm{Na}$ ture (Lond.). 346:574-576.

66. Baum, H., P. Butler, H. Davies, M. J. E. Sternberg, and A. K. Burroughs. 1993. Autoimmune disease and molecular mimicry; an hypothesis. TIBS (Trends Biochem. Sci.). 18:140-144.

67. Chicz, R. M. R. G. Urban, W. S. Lane, J. C. Gorga, L. J. Stern, D. A. A. Vignali, and J. L. Strominger. 1992. Predominant naturally processed peptides bound to HLA-DR1 are derived from MHC-related molecules and are heterogenous in size. Nature (Lond.). 358:764-768.

68. Woodland, D. L., and M. A. Blackman. 1993. How do T-cell receptors, MHC molecules and superantigens get together? Immunol. Today. 14:208-212.

69. Yasuda, M., H. Abe, and T. Obinata. 1992. Cloning and sequence analysis of cDNA encoding chicken cardiac C-protein. Cell Struct. Funct. 17:525. 